\title{
Bone Tissue
}

National Cancer Institute

\section{Source}

National Cancer Institute. Bone Tissue. NCI Thesaurus. Code C13076.

The mineralized osseous tissue that gives rigidity to the bones and forms its honeycomb-like three-dimensional internal structure. 